\title{
CONSOLIDATION INTEGRATED BUOYANCY EQUATION FOR SOFT GROUND IMPROVED WITH LIGHTWEIGHT POLYURETHANE FOAM
}

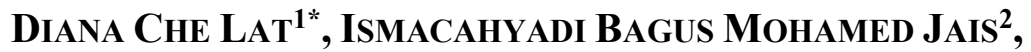 \\ NAZri Ali ${ }^{3}$, Nor ZurairahetTy Mohd Yunus ${ }^{3}$, Nor Hibatul Wafi Nor \\ ZARIN $^{4}$ AND ATIQAH NAJWA ZAINUDDIN ${ }^{1}$ \\ ${ }^{I}$ Faculty of Civil Engineering, Universiti Teknologi MARA (UiTM) Johor, \\ Pasir Gudang Campus, 81750, Masai, Johor \\ ${ }^{2}$ Faculty of Civil Engineering, Universiti Teknologi MARA (UiTM) Selangor, \\ Shah Alam Campus, 40450, Shah Alam, Selangor \\ ${ }^{3}$ School of Civil Engineering, Faculty of Engineering, Universiti Teknologi Malaysia, \\ 81310 Johor Bahru, Johor \\ ${ }^{4}$ Cawangan Kejuruteraan Cerun, JKR Malaysia, Jalan Sultan Salahuddin, \\ 50582 Kuala Lumpur \\ *Corresponding author: dianacl@uitm.edu.my
}

(Received: $2^{\text {nd }}$ January 2021; Accepted: $30^{\text {th }}$ October 2021; Published on-line: $4^{\text {th }}$ January 2022)

\begin{abstract}
Consolidation settlement occurs when a saturated soil is subjected to an increase in overburden pressure that causes a volume change in the soil. When a lightweight material is used as a ground improvement, the stress is reduced as the soft soil is partially removed and replaced by the lightweight material. In addition, the improved ground with lightweight material has a potential to uplift due to the buoyancy of lightweight material. The uplift force reduces the stress imposed on the underlying soil as it acts in the upward direction, thus further reducing the consolidation settlement. This study is executed to produce an alternative equation for consolidation settlement incorporating the buoyancy effect for lightweight polyurethane (PU) foam as a ground improvement method. A Rowe Cell consolidation laboratory test was conducted on untreated marine clay soil as well as on improved marine clay with different thicknesses of lightweight PU foam. Validation of the laboratory test results was done by finite element analysis, PLAXIS 2D. The thickness of PU foam governs the buoyancy and the hydrostatic pressure of water displaced by $\mathrm{PU}$ foam, which is incorporated in the alternative equation. The alternative consolidation settlement equation is applicable for ground improved with lightweight polyurethane foam and found to be more economical and practical as the buoyancy is taken into account in the equation.
\end{abstract}

ABSTRAK: Mendapan pengukuhan berlaku apabila tanah tepu mengalami peningkatan tekanan beban yang menyebabkan perubahan isipadu tanah. Apabila bahan ringan digunakan sebagai penambahbaikan tanah, tekanan akan berkurang kerana sebahagian tanah lembut dikeluarkan dan diganti dengan bahan ringan. Selain itu, tanah yang diperbaiki dengan bahan ringan berpotensi untuk terangkat ke atas keranan daya apung bahan ringan. Daya angkat bahan ringan mengurangkan tekanan yang dikenakan ke atas tanah kerana daya bertindak ke arah atas, dan seterusnya megurangkan mendapan pengukuhan. Kajian ini dijalankan untuk menghasilkan persamaan alternatif bagi mendapan pengukuhan dan digabungkan dengan kesan daya apung untuk busa poliuretena ringan (PU) sebagai kaedah penambahbaikan tanah. Ujian makmal mendapan pengukuhan menggunakan peralatan Rowe Cell dilakukan pada tanah liat marin yang asal serta yang diperbaiki dengan ketebalan busa PU ringan yang berbeza. 
Pengesahan hasil ujian makmal dilakukan dengan analisis elemen terhingga, PLAXIS 2D. Ketebalan busa PU mempengaruhi daya apung dan tekanan hidrostatik bagi kedalaman air yang disesarkan oleh busa PU dan digabungkan dalam persamaan alternatif. Persamaan alternatif mendapan pengukuhan tersebut boleh digunapakai untuk pembaikan tanah menggunakan bahan ringan busa poliuretena dan didapati menjimatkan kos dan praktikal kerana keapungan diambilkira didalam persamaan tersebut.

KEYWORDS: soft ground; consolidation settlement; buoyancy; polyurethane; lightweight

\section{INTRODUCTION}

Construction on soft clay causes consolidation settlement of the soil due to increased overburden load and low permeability of clay soil. In order to reduce the overburden load, lightweight materials are proposed as a ground improvement for soft clay. Some of the lightweight fill materials such as foamglass, sawdust and bark residue, foamed concrete, lightweight clay aggregate, shredded tires, floating bamboo and plastic bags [1,2] have been investigated as a ground improvement method. Low et al. [3] proposed a new floating foundation system, namely a lightweight concrete infill buoyant system whereby plastic bags, used tires, and tubes were used as a lightweight material for foundation construction whilst bamboo and bakau were used to encapsulate the waste materials and form a composite floating foundation. On top of that, lightweight foams are also currently in demand due their ability to enable fast construction work with less manpower as the foam can be pre-fabricated in the factory.

This study focuses on lightweight foam, namely polyurethane (PU) foam, as a ground improvement method. In 1937, Dr. Otto Bayer was the first person to produce and investigate polyurethane [4]. Polyurethane is a class of polymers with a mix of polyol ($\mathrm{OH})$ and isocyanate (-NCO) that react during polymerization of polyurethane [5-8]. Nowadays, PU foams are recognized as one of the most crucial classes of polymers that transform the quality of human life [9]. It was predicted that the worldwide consumption of PU will be over 79 billion USD in 2021 [10]. As the demand increases, the sustainable production of PU foam is very crucial. Polyol can be produced from bio-based oil and crude glycerol [11-13] whilst isocyanate can be produced from non-isocyanate material (NIPU), which is non-petroleum based [14-17].

When this lightweight material is used as a ground improvement method on saturated soil, buoyancy of the material may cause uplift. Excessive uplift may damage the structure founded on it [18]. The buoyancy is an upward force exerted by a fluid that acts on an immersed object. Over two millennia ago, Archimedes of Syracuse [19] developed the Archimedes' principle, which states that "any object, wholly or partially immersed in a fluid, is buoyed up by a force equal to the weight of the fluid displaced by the object." The buoyancy acting on an underground structure in either shallow or deep foundation was measured and compared with Archimedes' principle [20-22]. Frydelund and Aaboer [23] had reported on a few failure cases of embankment, which was founded on lightweight geofoam due to buoyancy. In 1987, the first lightweight geofoam, namely expanded polystyrene foam (EPS) fill built-in Norway, floated off during an unpredicted rainfall season and rising flood waters. In Thailand, the unexpected water level washed away a road filled with EPS. The geofoam experienced uplift during flooding as the weight of earthfill overlying the foam was inadequate. Various methods have been proposed to prevent the effect of hydrostatic uplift pressure, such as providing adequate load overlying the foam, proper drainage underneath the foam and installation of ground anchors [24]. 
Consolidation settlement occurs when a saturated soil is subjected to an increase in overburden pressure that causes a soil volume change. The consolidation settlement reduces as the saturated soil is partially removed and replaced with the lightweight PU foam. In addition, the PU foam that is immersed in water as well as in saturated soil, produces a buoyant force that acts in an upward direction that might further reduce the consolidation settlement of the soil. Therefore, the consolidation settlement considering the effect of buoyancy for the ground improved with PU foam is investigated in this study.

\section{METHODOLOGY}

The consolidation settlement test for untreated and treated soil samples with different thickness of PU foam was executed utilizing Rowe Cell. The Rowe Cell was developed at Manchester University, UK by Professor Rowe [25]. The detailed description of the principles and practice of Rowe Cell testing are given in Head [26]. In the Rowe Cell, the test sample is loaded hydraulically by water pressure acting on a flexible diaphragm. Drainage of the sample can be controlled and pore water pressure is measured [27]. The advantages of Rowe Cell over Oedometer test includes minimum vibration effects, measurable pore water pressure, as well as the execution of the saturation process [26]. Rowe Cell differs from Oedometer as the load is applied continuously instead of incrementally. Cell pressure, back pressure, and pore water pressure drainage line are attached on top and bottom part of the Rowe Cell apparatus as shown in Fig. 1.

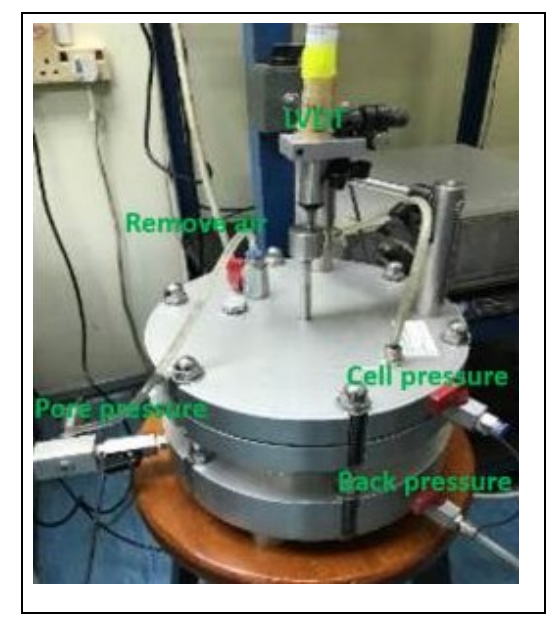

Fig.1: Rowe Cell apparatus.

\subsection{Rowe Cell Consolidation Test on Saturated Marine Clay with PU Foam Partial Replacement}

The test procedure for Rowe Cell consolidation test on saturated clay is as shown in Fig. 2. Prior to the testing, the calibration of the Rowe Cell apparatus was performed according to BS1377-Part 6:1990 [28] and Head [26]. For sample preparation, one kilogram of oven dried soil sample was mixed with distilled water at 1.4 times the liquid limit to form a slurry before placing it into the Rowe Cell mould. The PU foam is produced by mixing polyol and isocyanate until it reacts, expands and hardens to form PU. Next, the sample of soil is placed inside the mould followed by the replacement of PU foam on the soil sample. It was followed by the placement of the top cell which was attached to LVDT, load cell, and cell pressure. Back pressure and pore pressure were attached to the bottom cell. The determination of consolidation and buoyancy behaviour of the clay soil improved with PU foam were carried out on a few samples of PU foam. 
Partial replacement of the soft clay with PU foam was done at shallow depth. Thus, in this laboratory test, the thickness of soft clay was $25 \mathrm{~mm}$ whilst the thicknesses of PU foam were $5 \mathrm{~mm}, 10 \mathrm{~mm}, 15 \mathrm{~mm}$ and $20 \mathrm{~mm}$ which were equivalent to $20 \%, 40 \%, 60 \%$ and $80 \%$ of PU foam to initial soft clay thickness respectively. In general, there were two phases during the consolidation integrated buoyancy test: the saturation and consolidation phases. The saturation process was carried out by applying cell pressure and back pressure alternately until Skempton's degree of saturation value, $\beta$ equalled or exceeded 0.95.

During the consolidation process, the samples were tested in $150 \mathrm{~mm}$ diameter mould of Rowe Cell with the effective overburden pressure of 10, 20, 50, 100, 200 and $400 \mathrm{kPa}$. The test procedures are described in detail in BS1377-Part 6:1990b for step-loading test using Rowe Cell [28]. All samples for four (4) different polyurethane foam thicknesses and untreated soil samples were tested and the data recorded using Data System 7.2 (DS7) software by ELE International.

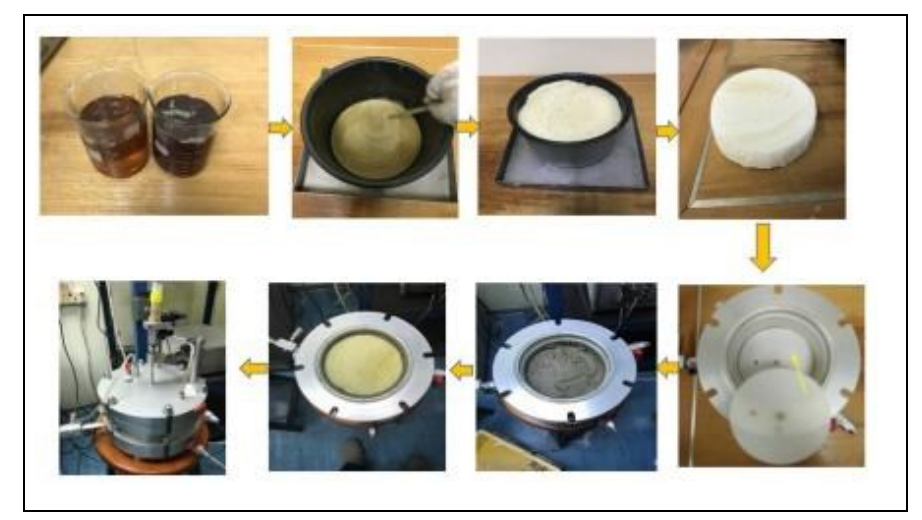

Fig. 2: Procedure of Rowe Cell consolidation test.

\subsection{The Validation of Rowe Cell Test with Finite Element Model PLAXIS 2D}

The validation of Rowe Cell laboratory test results was done with finite element model of PLAXIS 2D [29]. The finite element replicates the condition of PU foam construction at a shallow depth of road/walkway foundation and the typical cross-section is as shown in Fig. 3. The material model used in the finite element analysis was a plane strain with 15 nodes with a standard fixities boundary. Under long structure, the strain in the longitudinal direction will be zero (except at each end), therefore, strain takes places only in the plane of cross-section producing plane strain with effective volumetric modulus, K' subject to effective Young's Modulus, E' and Poisson's ratio, v' as in Eq. (1):

$$
\mathrm{K}^{\prime}=\mathrm{E}^{\prime} /\left[2\left(1+v^{\prime}\right)\left(1-2 v^{\prime}\right)\right]
$$

The soft clay was in undrained condition as it is the most critical condition that the saturated clay experienced during and after construction due to very low permeability of the soil. However, the shear strength parameter input in soft-soil creep model in PLAXIS only allowed the use of effective shear strength parameter as the water is not supposed to resist any shear stress. The finite element model of the existing condition of the site before ground improvement is as shown in Fig. 4 whilst Fig. 5 shows the finite element model of the site after ground improvement with PU foam partial replacement at shallow depth of soft clay. Table 1 shows the details of subsoil and PU properties used in the finite element model whilst Fig. 6 shows the detailed cross-section for the ground improved with $1 \mathrm{~m}$ thickness of PU foam as an example. The effective shear strength parameters of the clay 
were obtained from the consolidated undrained (CU) triaxial strength test whilst the properties of PU foam were obtained from the unconfined compressive strength test. The finite element model for the existing condition consisted of $2.5 \mathrm{~m}$ thick soft clay, followed by a hard layer of about $10 \mathrm{~m}$ thick. A layer of PU foam was used as a ground improvement method varying in thickness from $0.5 \mathrm{~m}, 1 \mathrm{~m}, 1.5 \mathrm{~m}$ and $2 \mathrm{~m}$, which was equivalent to $20 \%, 40 \%, 60 \%$ and $80 \%$ of initial soft clay thickness, respectively. This was equivalent to the thickness of PU foam used in Rowe Cell consolidation test, as shown in Table 2. The geotextile separator shown in Figs. 4 and 5 functioned as a separator between soft clay and PU foam which did not contribute any strength, therefore, it was not modelled in PLAXIS. The FEM analysis was executed for 5 years which is equivalent to $90 \%$ degree of consolidation based on the coefficient of consolidation, $\mathrm{C}_{\mathrm{V}}$ obtained for the clay sample.

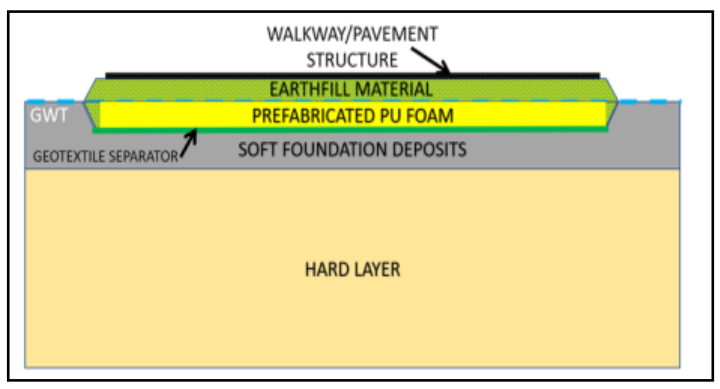

Fig. 3: Typical cross-section of PU foam construction at shallow depth of road foundation.

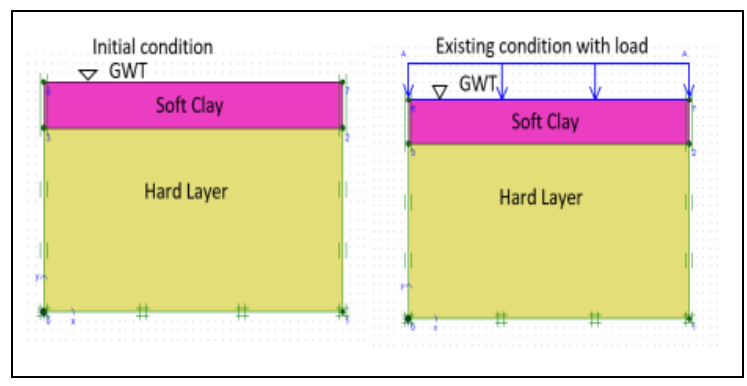

Fig. 4: Cross-section of existing site in finite element model.

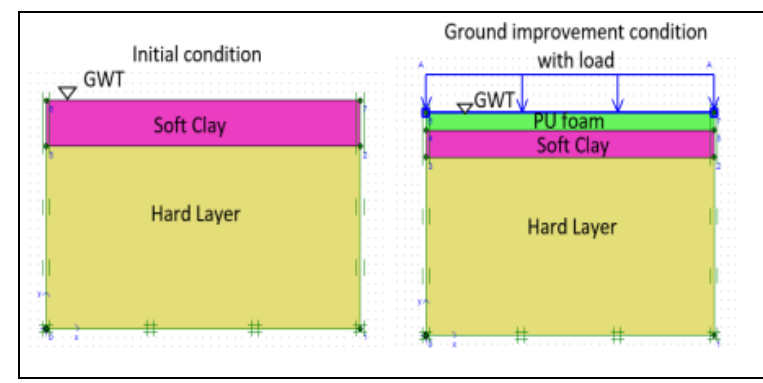

Fig. 5: Cross-section of the site after ground improvement with PU foam

partial replacement at shallow depth of soft clay.

Table 1: Properties of soil and PU

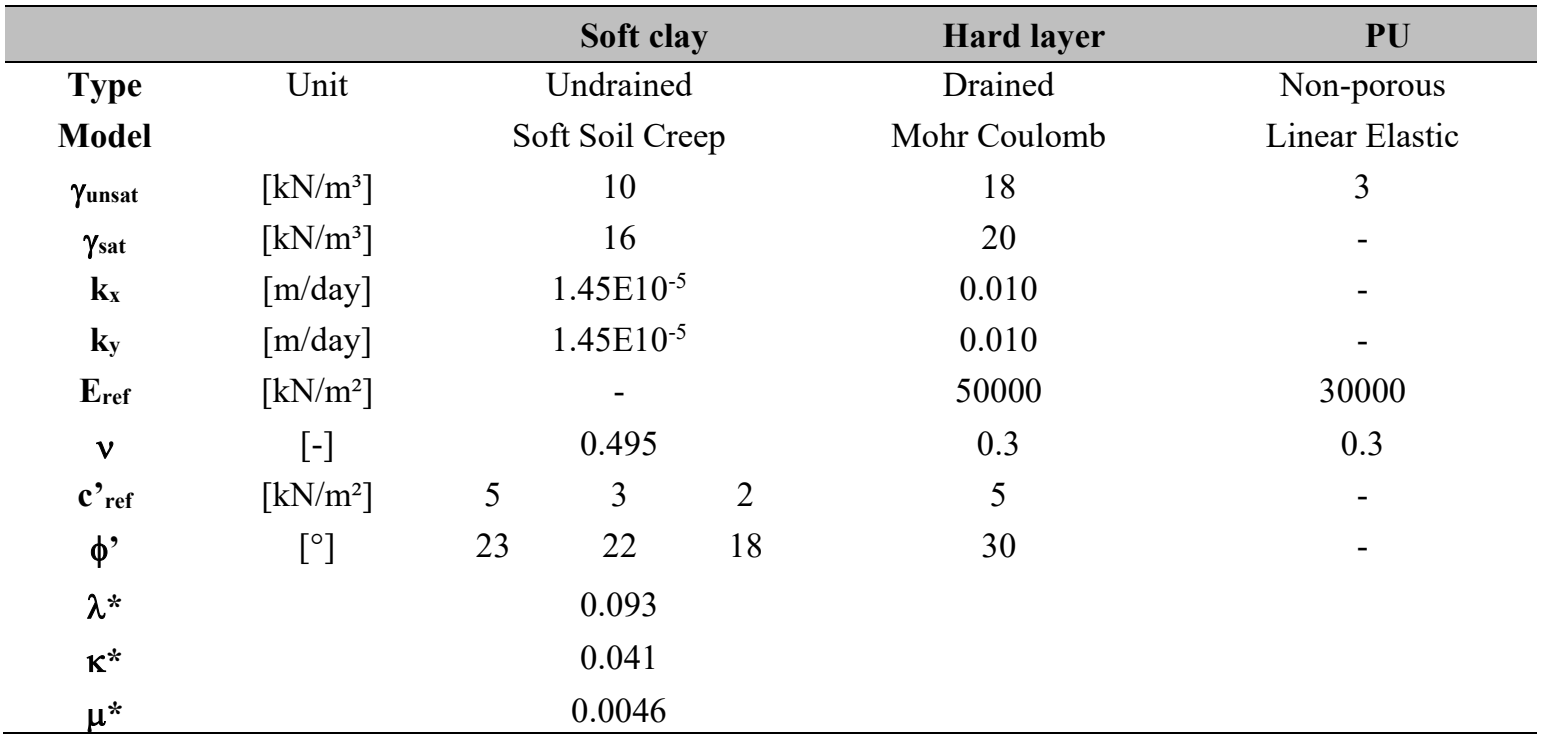




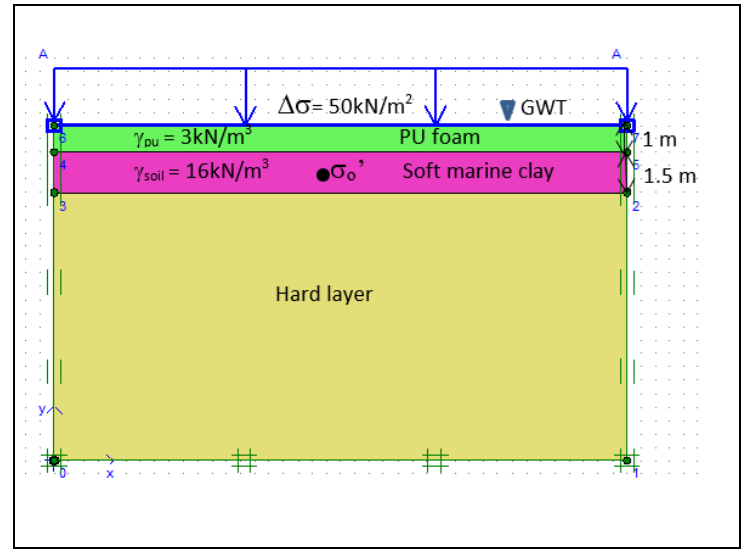

Fig. 6: Cross-section of improved ground with subsoil properties.

Table 2: The details of PU foam thickness in FEM analysis and Rowe Cell laboratory test

\begin{tabular}{ccc}
\hline $\begin{array}{c}\% \text { PU foam to initial } \\
\text { soft clay thickness }\end{array}$ & $\begin{array}{c}\text { PU foam thickness in Rowe Cell lab }(\mathrm{mm}) \\
\text { (initial soft clay thickness }=25 \mathrm{~mm} \text { ) }\end{array}$ & $\begin{array}{c}\text { PU foam thickness in FEM (m) } \\
\text { (initial soft clay thickness }=2.5 \mathrm{~m} \text { ) }\end{array}$ \\
\hline $20 \%$ & 5 & 0.5 \\
$40 \%$ & 10 & 1 \\
$60 \%$ & 15 & 1.5 \\
$80 \%$ & 20 & 2.0 \\
\hline
\end{tabular}

\section{RESULTS AND DISCUSSION}

The condition of the PU foam before and after Rowe Cell test is shown in Fig. 7. The PU foam did not show any distress or crack after the consolidation process, indicating that it was highly resistant to compression. Therefore, PU foam is currently one of the best alternative ground improvement methods for soft soil because of its many advantages [3032]. The design of $P U$ foam as a ground improvement takes into account the effect of buoyancy in the consolidation process. Thus, the current consolidation settlement equation was modified to integrate the buoyancy effect of the PU foam. The buoyant force, Fb acts in the opposite direction to the overburden load pressure $(\mathrm{P})$ as shown in Fig. 8. Therefore, a buoyant force is able to reduce the consolidation settlement of the soft ground due to the increased load.

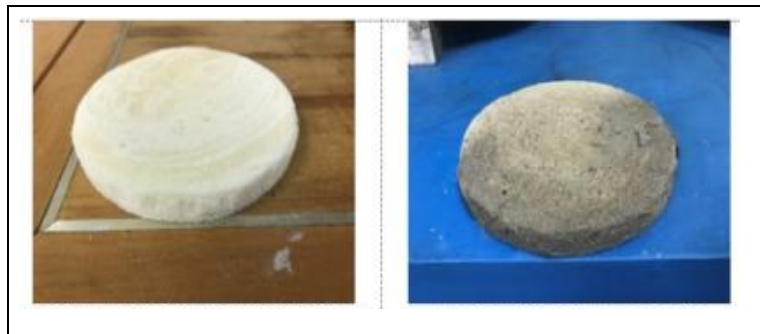

Fig. 7: Conditions of PU foam before and after Rowe Cell consolidation test.

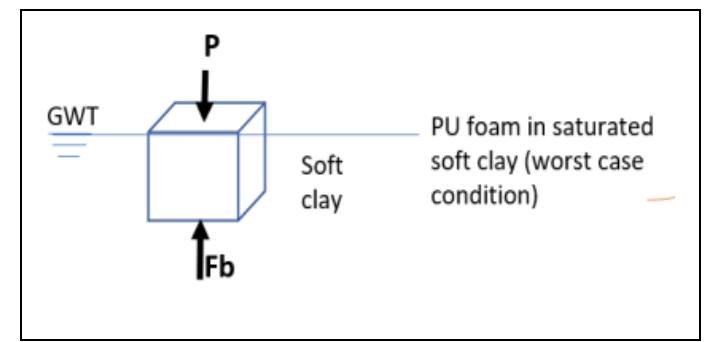

Fig. 8: Buoyant force acting on PU foam at shallow depth of soft clay.

From the Rowe Cell laboratory consolidation test as well as the finite element model, the compressibility index of the soil improvements with $\mathrm{PU}$ foam, $\mathrm{Cc}_{\mathrm{pu}}$ for different thickness of PU foam were obtained. Existing consolidation settlement as in Eq. (2) is used to calculate the existing ground as well as improved ground based on the $\mathrm{Cc}_{\mathrm{pu}}$ 
obtained. However, the consolidation settlement equation based on the compressibility index, $\mathrm{Cc}$, of existing soft clay is more practical instead of $\mathrm{Cc}_{\mathrm{pu}}$, therefore, Eq. (2) was modified to produce an alternative equation that incorporated the buoyant force, $\mathrm{Fb}$, and hydrostatic pressure at the PU foam area, $\mathrm{Uh}_{\mathrm{pu}}$, as in Eq. (3). Since PU foam is a lightweight material, the buoyant force is introduced by the weight of water that is displaced by the PU foam, Fb, as in Eq. (4) and this is in line with Archimedes' principle [19] and equivalent to the hydrostatic pressure at the PU foam area $\mathrm{Uh}_{\mathrm{pu}}$. The buoyant force acts in the opposite direction to the overburden load, and as the PU foam thickness increases, the buoyant force increases as more water is displaced by the PU foam in the saturated soil. Therefore, a buoyant force is able to reduce the consolidation settlement of soft ground, $\delta$.

$$
\delta_{\mathrm{pu}}=\frac{C_{c} p u \cdot H}{1+e_{0}} \log \left[\frac{\sigma_{0}^{\prime}+\sigma p u+\Delta \sigma}{\sigma_{0}^{\prime}+\sigma p u}\right]
$$

The initial effective stress in the alternative equation of consolidation settlement integrated buoyancy for the ground improved with PU foam as in Eq. (3) refers to the effective stress of the soft clay soil, $\sigma_{\mathrm{o}}$ ', the stress from PU foam $\sigma_{\mathrm{pu}}$ and the hydrostatic pressure at $\mathrm{PU}$ foam, $\mathrm{Uh}_{\mathrm{pu}}$. The increase in the effective stress refers to the applied load pressure, $\Delta \sigma$ and the buoyant force, $\mathrm{Fb}$, which acts in the opposite direction of the applied load pressure, $\Delta \sigma$. Fig. 9 shows an example of the improved ground condition with the detailed parameters for elaboration on the alternative equation. The alternative equation applicable for normally consolidated soil with an overconsolidated ratio OCR value of 1 .

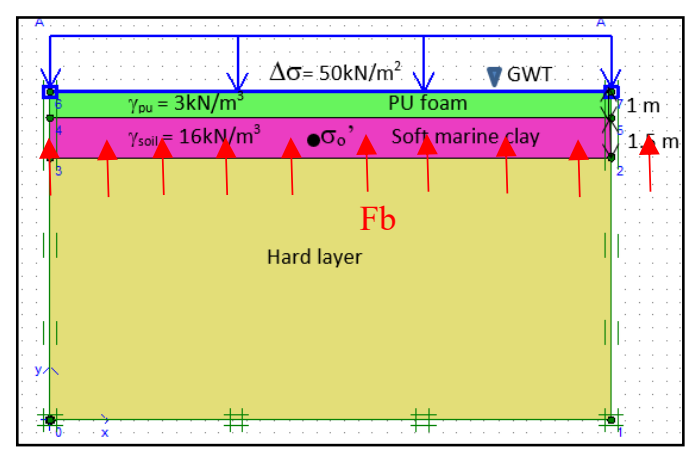

Fig. 9: Example of improved ground condition with detailed parameters for elaboration of the alternative equation.

$$
\begin{aligned}
\delta & =\frac{C_{C} H}{1+e_{0}} \log \left[\frac{\sigma_{0}^{\prime}+\sigma p u+U \not h u+\Delta \sigma-\not b b}{\sigma_{0}^{\prime}+\sigma p u+U h p u}\right] \\
\delta & =\frac{C_{c} H}{1+e_{0}} \log \left[\frac{\sigma_{0}^{\prime}+\sigma p u+\Delta \sigma}{\sigma_{0}^{\prime}+\sigma p u+U h p u}\right]
\end{aligned}
$$

where:

$\mathrm{C}_{\mathrm{c}}=$ compression index for marine clay soil

$\mathrm{H}(\mathrm{m})=$ drainage path length

$\mathrm{e}_{\mathrm{o}}=$ initial void ratio

$\sigma_{\mathrm{o}}{ }^{\prime}(\mathrm{kPa})=$ initial effective stress

$\sigma_{\mathrm{pu}}(\mathrm{kPa})=$ stress from PU foam

$\Delta \sigma(\mathrm{kPa})=$ the increase of overburden stress 
$\mathrm{F}_{\mathrm{b}}(\mathrm{kN})=$ buoyant force per square meter area $=$ weight of water displaced by PU foam $\left(\mathrm{Uh}_{\mathrm{pu}}\right)$

$$
\mathrm{F}_{\mathrm{b}}=\mathrm{Uh}_{\mathrm{pu}}=\gamma_{\mathrm{w}} \cdot \mathrm{T}_{\mathrm{pu}}
$$

Figure 10 shows the relationship between load pressure and settlement for the ground improved with PU foam with $20 \%$ PU foam thickness to initial soft clay. The comparisons are made between the results of Rowe Cell consolidation laboratory test (\%PU-Lab), finite element model (\%PU-FEM), consolidation settlement integrated buoyancy equation (\%PU new eq) and existing consolidation settlement equation (\%PU ex eq). All the results show good agreement with each other with the difference tolerance less than $20 \%$ except for the existing consolidation equation whereby the settlement value is overpredicted and the tolerance is more than $20 \%$. The results are also compared with the untreated soil sample based on Rowe Cell consolidation laboratory test and finite element model in the same graph. For untreated soil samples, the settlement value obtained from Rowe Cell laboratory test (Soil only-Lab) is very close to the finite element analysis results (Soil only-FEM). The settlement reduces with the ground improvement of $20 \%$ PU foam to initial soft clay thickness. A similar trend occurs for other thicknesses of PU foam of $40 \%$, $50 \%, 60 \%$ and $80 \%$ as shown in Figs. 11 to 14 .

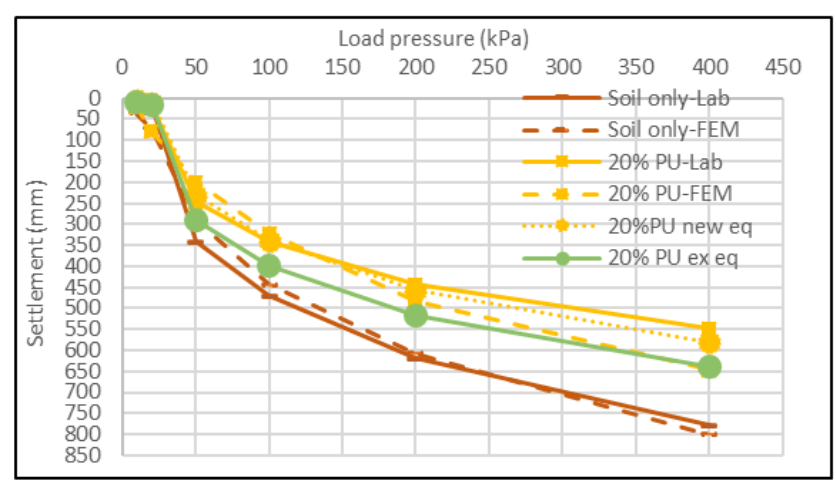

Fig. 10: Load pressure and settlement relationship for untreated and improved soil sample (20\% PU foam to initial soft clay depth)

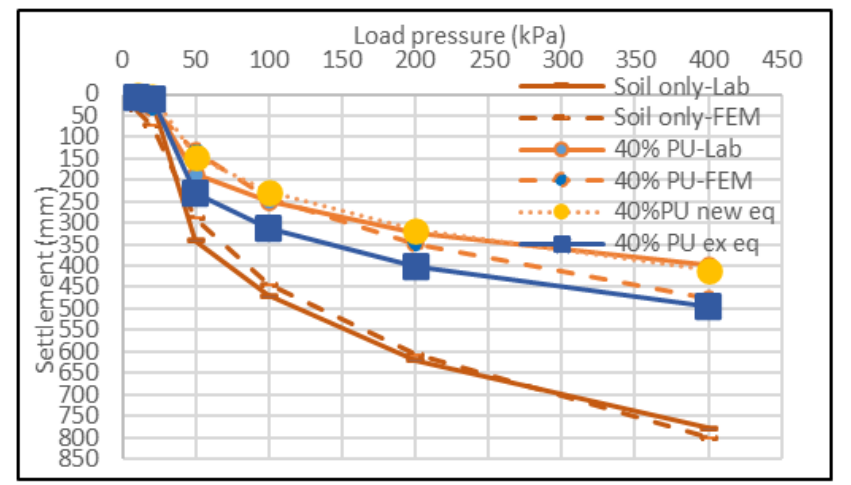

Fig. 11: Load pressure and settlement relationship for untreated and improved soil sample ( $40 \%$ PU foam to initial soft clay depth). 


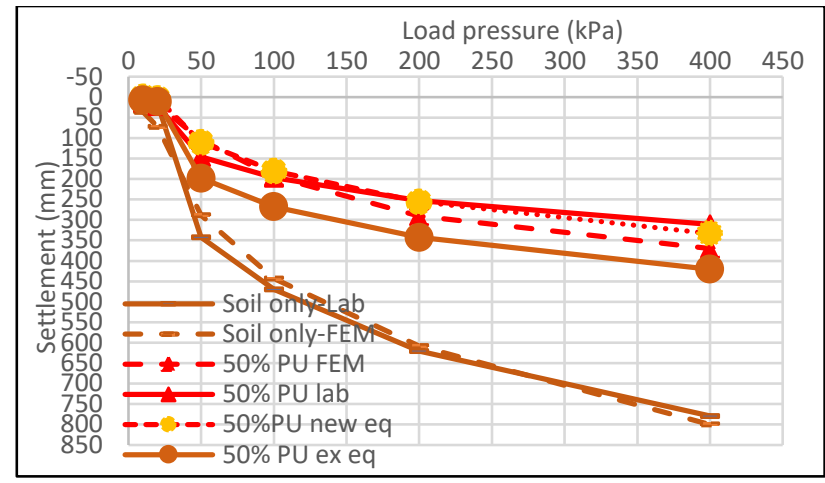

Fig. 12: Load pressure and settlement relationship for untreated and improved soil sample (50\% PU foam to initial soft clay depth).

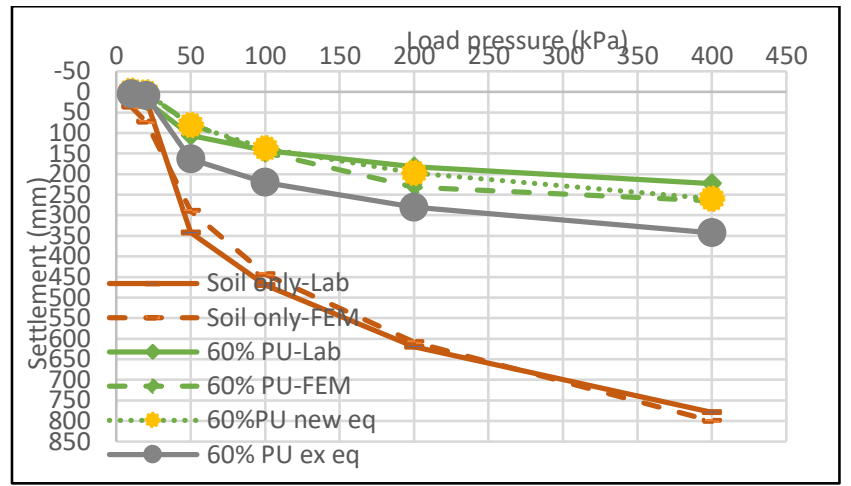

Fig. 13: Load pressure and settlement relationship for untreated and improved soil sample (60\% PU foam to initial soft clay depth).

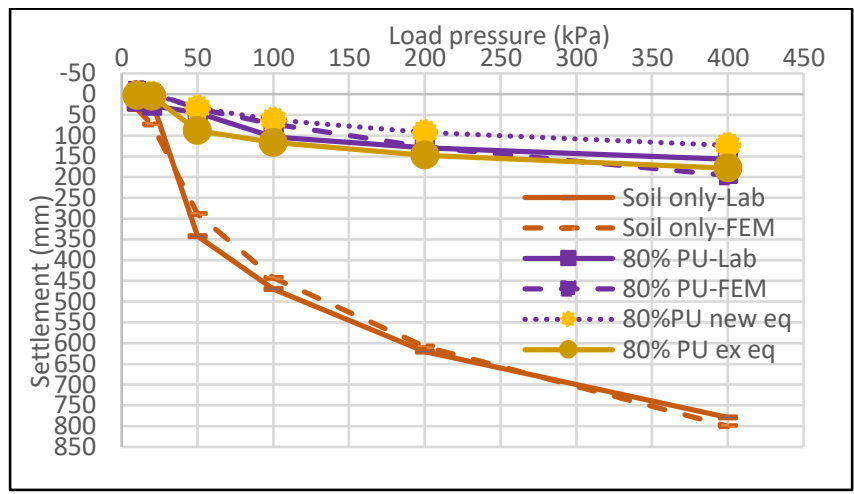

Fig. 14: Load pressure and settlement relationship for untreated and improved soil sample ( $80 \%$ PU foam to initial soft clay depth).

All the samples of improved soil with PU foam indicate that the settlement value is overpredicted by the existing consolidation settlement equation. The existing equation does not take into consideration the buoyancy effect of the PU foam to the consolidation settlement of the ground. Therefore, an alternative equation of consolidation settlement integrated buoyancy should be applied for improved ground with PU foam to avoid overprediction of settlement value thus more conservative and might increase the construction cost. Figure 15 shows the combination of load pressure vs consolidation settlement for the soil improved with different thickness of PU foam ranging from $20 \%$ to $80 \%$ of PU foam to initial soft clay thickness as well as the untreated soil sample. The trend shows that the consolidation settlement reduces with the increase in PU foam 
thickness. With the increase in PU foam thickness, the overburden pressure decreases as the lightweight PU foam has partially replaced the soft soil and the upward buoyant force increases as well, thus the settlement reduces.

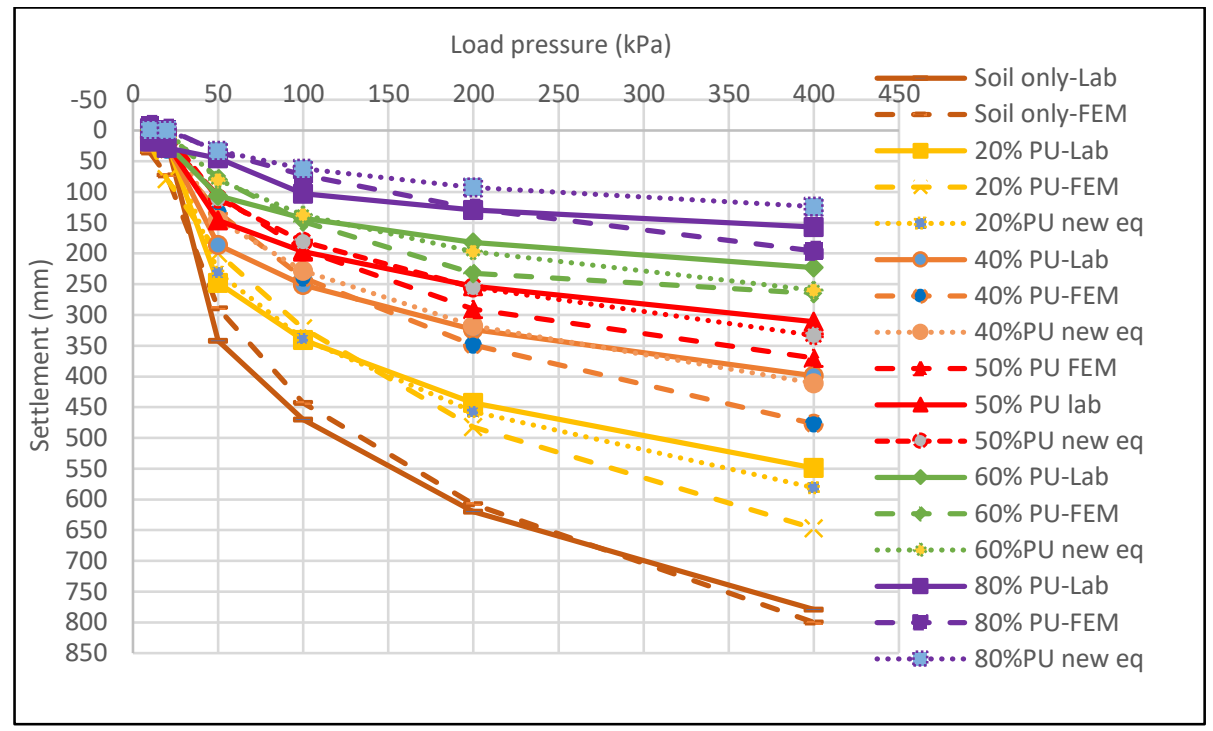

Fig. 15: Load pressure and settlement relationship for untreated and improved soil sample with different thickness of PU foam to initial soft clay depth.

\section{CONCLUSION}

The design of lightweight PU foam as a ground improvement method should take into account the effect of buoyancy in the consolidation process. This is due to the density of PU foam which is lower than water as well as the saturated soil which has the tendency of uplift due to buoyancy. Based on the results of Rowe Cell consolidation laboratory test as well as the finite element model, PLAXIS, the existing consolidation settlement equation was modified to integrate the buoyancy effect of the PU foam as a ground improvement. The buoyant force that is introduced by $\mathrm{PU}$ foam, $\mathrm{Fb}$, equivalent to the weight of water displaced by PU foam is in line with Archimedes' principle and acts in the opposite direction of the overburden load pressure. The consolidation settlement value of the improved soil samples was overpredicted by the existing consolidation settlement equation as the buoyancy effect of the PU foam to the consolidation settlement of the ground was not accounted for. Therefore, an alternative equation of consolidation settlement integrated buoyancy might be applied for the ground improved with PU foam in order to avoid overprediction of consolidation settlement value; which is more conservative and increases the construction cost.

\section{REFERENCES}

[1] Ibrahim A, Huat BB, Asadi A, Nahazanan H. (2014) Foundation and embankment construction in peat: An overview. Electronic Journals of Geotechnical Engineering, 19: 10079-10094.

[2] Zhang J, Zhai JF, Wang XM. (2014) Instrumented full scale test and numerical analysis to investigate performance of bamboo pile-mattress system as soil reinforcement for coastal embankment on soft clay. Applied Mechanics and Materials, 501: 2132-2137.

[3] Low KS, Tioh NH, Ng SC. (2013) Lightweight concrete infill buoyant platform and the method thereof. World Inventor Award Festival, 2013 
[4] Howard GT. (2012) Polyurethane biodegradation. Environmental Science and Engineering 2012. Springer-Verlag Berlin Heidelberg. https://doi.org/10.1007/978-3-642-23789-8_14

[5] Bayer O. (1947) Polyurethanes. Mod Plast, 24:149-152.

[6] Buzzi O, Fityus S, Sasaki Y, Sloan S. (2008).. Structure and properties of expanding polyurethane foam in the context of foundation remediation in expansive soil. Mechanics of Materials, 40: 1012-1021.

[7] Buzzi O, Fityus S, Sasaki Y, Sloan S. (2010) Use of expanding polyurethane resin to remediate expansive soil foundation. Canadian Geotechnical Journal, 47: 623-634.

[8] Badri K. (2012). Biobased polyurethane from palm kernel oil based polyol. License InTech 2012

[9] Ionescu M. (2005) Chemistry and technology of polyols for polyurethanes, Rapra Technology Limited, Shawbury, UK, ISBN 1859574912

[10] Polyurethane global market size forecast 2021. https://www.statista.com/statistics/ 720449/global-polyurethane-market-size-forecast/ accessed on 25 September 2019

(11] Zeltins V, Yakushin V, Cabulis U, Kirpluks M. (2017) Crude tall oil as raw material for rigid polyurethane foams with low water absorption. Solid State Phenom, 267: 17-22.

[12] Athawale VD, Nimbalkar RV. (2011) Polyurethane dispersions based on sardine fish oil, soybean oil, and their interesterification products. J. Dispers. Sci. Technol, 32: 1014-1022.

[13] Pawar MS, Kadam AS, Dawane BS, Yemul OS. (2016) Synthesis and characterization of rigid polyurethane foams from algae oil using biobased chain extenders. Polym. Bull, 73: 727-741.

[14] Figovsky OL. (2000) Hybrid non-isocyanate polyurethane network polymers and composites formed therefrom. U.S. Patent, 6:120,905.

[15] Guan J, Song Y, Lin Y, Yin X, Zuo M, Zhao Y, Tao X, Zheng Q. (2011) Progress in study of non-isocyanate polyurethane. Ind. Eng. Chem. Res, 50: 6517-6527.

[16] Li Z, Zhao Y, Yan S, Wang X, Kang M, Wang J, Xiang H. (2008) Catalytic synthesis of carbonated soybean oil. Catal. Lett, 123: 246-251.

[17] Tamami GWSS .(2004). Using tetrabutylammonium bromide catalyst. U.S. Patent 20040230009 A1.

[18] Rathod MA, Upadhyaya DS, Panchal SL. (2014) Preventation of hydrostatic uplift pressure underneath of basement floor slab in high water table area. International Journal of Futuristic Trends in Engineering and Technology, 1(03): 72-75.

[19] Heath TL. (1897) The worlds of Archimedes. Edited in Modern Notation with Introductory chapters, Cambridge University Press, 257

[20] Song LH, Liu Y, Mei GX, Zai JM. (2008) Experimental study on buoyancy effect on deep foundation in clay. Hydrogeology \& Engineering Geology, 35(6): 80-84.

[21] Song L, Kang X, and Mei G. (2017) Buoyancy force on shallow foundations in clayey soil: an experimental investigation based on the Half Interval Search, Ocean Engineering, 129: 637-641.

[22] Ni P, Kang X, SongL, Mei G, Zhao Y. (2019) Model tests of buoyant force on underground structures. Journal of Testing and Evaluation, 47(2): 1216-1235.

[23] Frydelund TE, Aaboer R. (2002) Lightweight filling materials for road construction. EPS Geofoam 3rd International Conference 2002, Salt Lake City

[24] Stephen S. (2016) Pressure reduction on wide culverts with EPS geofoam backfill. Dissertations-ALL. 548. https://surface.syr.edu/etd/548

[25] Rowe PW, Barden L. (1966) A new consolidation cell. Géotechnique, 16(2): 162-170. https://doi.org/10.1680/geot.1966.16.2.162

[26] Head KH (1985). Manual of soil laboratory testing, 3: Effective stress tests pp.1129-1225

[27] Premchitt J, Ho KS, Evans NC. (1995) Conventional and CRS Rowe cell consolidation test on some Hong Kong clays.

[28] BS1377-Part 6:1990: Consolidation and permeability tests in hydraulic cells and with pore pressure measurement.

[29] Brinkgreve RBJ (2002). Plaxis 2D Version 8, Material Models Manual 
[30] Saleh S, Ahmad K, Mohd Yunus N. (2020) Evaluating the toxicity of polyurethane during marine clay stabilisation. Environ Sci Pollut Res, 27: 21252-21259. https://doi.org/10.1007/s11356-020-08549-y

[31] Al-Atroush ME, Sebaey TA. (2021) Stabilization of expansive soil using hydrophobic polyurethane foam: A review. Transportation Geotechnics, 27:100494. https://doi.org/10.1016/j.trgeo.2020.100494

[32] Abdurahman MN, Kasbi Basri AZ, Kassim A (2021). Assessment of physical and mechanical properties of polyurethane as ground improvement material for peat. Neutron, 20(2): 149156. https://doi.org/10.29138/neutron.v21i1.99 